\title{
The Model of Quality Control System in CPA Firms in Malang City, Indonesia
}

\author{
Fitri Nur Elisa ${ }^{1)}$, Eka Ananta Sidharta ${ }^{2)}$, Dodik Juliardi ${ }^{3)}$ \\ ${ }^{1}$ Pascasarjana, Universitas Negeri Malang \\ ${ }^{2}$ Fakultas Ekonomi, Universitas Negeri Malang \\ ${ }^{3}$ Fakultas Ekonomi, Universitas Negeri Malang
}

\begin{abstract}
Along with the public demands to deliver a business process that is managed well, the spotlight on the performance of public accountant are sharply occurs. It can not be separated from the business malpractice involving professional accountants who create public confidence in the public accounting profession to decrease. This phenomenon has impacted on the public accounting profession in Malang City, Indonesia. CPA Firms in Malang City must continue to improve the professionalism and quality of the audit in order to continue to preserve public confidence in the profession and also be able to compete with colleagues in the country and abroad. According required by the Public Accountants Professional Standards (SPAP), the firm must implement a quality control system. Quality control system should be comprehensive and should be designed in harmony with the organizational structure, policy and practice characteristics. It brings about a question: how are the models of quality control sistem in CPA Firms in Malang City?. This purpose of this study is to develop a deeper understanding how the quality control system in CPA Firms in Malang City. This research included in qualitative research. The results showed that CPA firms in Malang who is the subject of research belonging to a small local firm has implemented quality control system referring to auditing standards that have been determined. In carrying out the quality control, the firm meets the six elements of quality control that raises output auditor good performance so as to produce good quality audit. Model quality control on each CPA firms has similarities which control more informally run and the leadership of the party most responsible for the implementation of these controls. Similarity form of control is motivated by the contextual factors that same CPA firms and adherence to standards and codes of conduct are the same.
\end{abstract}

Key Words: Quality Control System, Auditor Performance, Audit Quality

\section{Introduction}

Public accountant plays an important role in the development of business environment in Indonesia. This is because of the significant contribution from the public accountant, who based themselves in CPA Firms, in providing the qualified legal opinion on the financial statements of an organization in order to confirm the status of the organization. The quality of audit from CPA Firms depends on the three standards of auditing; common standard, field work, and reporting.

Aside of the standards, auditor should also prioritize and obey the ethical code of their profession. In Indonesia, those ethics are called as Accountant Ethical Code of Indonesia. Article 1, verse 2 of Accountant Ethical Code of Indonesia stated that every member should maintain their integrity, objectivity, and independence in executing their professional work (Trisnaningsih, 2007:3). Therefore, it is expected that every auditor manages to be a qualified auditor as well as producing qualified auditing product. As what DeAngelo (1981:186) said that "The quality of audit means the probability of an auditor in finding and reporting fallacies and flaws in the financial statement which is being audited. This probability depends on the technical ability of the auditor (such as education, experience, professionalism), independence, and attitude in engaging in auditing program".

In regards with the society demand to conduct a well-managed business, the performance of public accountant had been a huge attention. This is also caused by the malpractice businesses that dragged the name of professional accountant, that eventually trigger the trust issues towards this profession. Hence, auditors need to elevate their professionalism in order to face the come obstacles in the future.

Professionalism of a profession require three main aspects to be possessed by the members of the profession, those are proficiency, knowledge, and character. Character means the professional personality, that is reflected in their behavior and ethical attitude (Ludigdo dan Machfoedz, 1999). Society and the user of accountant service will judge the professionalism of an accountant from their behavior and ethical attitude. This is inevitable for accountants are also business entity which should have a high level of competitiveness in order to save their position both in domestic and international level (Nugroho dan Chariri, 2012:1). 
These phenomena surely affect the public accountant in Malang City. Eventhough, the CPA Firms in Malang City is still considered as small local firms, but CPA Firms must maintain their professionalism fir the possible risks faced is not different from the big scale of CPA Firms. All CPA Firms should produce qualified audit result. Besides, by being professional and being competitive with others, OAF in Malang City will able to keep the society's trust and compete with their rivals both in domestic and international level. In order to maintain the professionalism in CPA Firms, according to the requirement of Professionalism Standard of Public Accountant (SPAP), CPA Firms need to implement quality control system.

Quality control system provides some guidance for CPA Firms in controlling the quality of their service in the firms by fulfilling the various standards issued by the Board of Professionalism Standard of Public Accountant of Public Accountant Institution of Indonesia (DSPAP IAPI) and Compartment Ethical Policy of Public Accountant issued by IAPI. The composed quality control system includes organization structure, policies, and procedure, those are set in order to assure that the union (the accountant union) complies with the Professionalism Standard of Public Accountant (SPAP). The quality control system has to be comprehensive and in line with the structure of organization, policies, and the type of practice (IAPI, 2011).

The concept above is in accordance with Theory of Contingency which stated that design or system of control depends on the context of the organization in which the controlling system is implemented (Fisher, 1998). Therefore, between one CPA Firm and the other might implement different quality control for their audit in order to create qualified audit product. The type, scope, and the procedure of the quality control set by CPA Firms depends on various factors, those are the size of CPA Firms, autonomy level of the staffs and branch offices, type of practices, organization, and the consideration of cost-advantage.

The implementation of quality control for audit in a CPA Firm allows the society believe that the auditors work in it to have the required knowledge and proficiency that prove the workers are expert in auditing and accounting. Every aspect in quality control system should be considered by the CPA Firms; how far the controlling system be implemented in the real practice, and how the policies and the procedure of quality control be implemented. All the aspects shall be related to each other.

After the quality control been set up, the quality of audit produces by the CPA Firms will be fixed. When we talk about the happening economic crisis in Indonesia, seemed that accountant mostly contributed to the fall. Because of their essential role in business world, accountants being accused as the black sheep of the degradation of Indonesia's economy. Hence, accountants urgently need to improve their performance. In order to do this, it is necessary to set the quality control for audit that is suitable with the current condition faced by CPA Firms. However, this contextual state require extensive attention in many aspects in developing the professionalism of public accountant, including a research and development in this subject. Thus, the researcher intends to contribute in developing the professionalism of public accountant by conducting a research in order to understand the practice of quality control system of auditing in CPA Firms in Malang City further".

\section{Research Approach and Design}

\section{Research Method}

This study designed to be qualitative research with the approach of phenomenology. According to Creswell (2012:20), Phenomenology is a strategy which the researcher identifies a phenomenon based on human's experience towards a particular happening. The type of phenomenology used is transcendental/psychological, that means the researcher develops structural description about someone else's experience, so that the researcher does not only rely on their own interpretation, but more on the experience of the participants (Creswell, 2007:59-60).

\section{Research Sample}

The sampling taking used here is nonprobability, that means the sampling is determined by the researchers themselves. The sampling techniques in this study is purposive sampling and snowball sampling. Purposive sampling is the technique to take sample from the subjects according to the specific criteria determined by the researcher. The subjects in this research is the board of CPA Firms, senior auditor, and junior auditor. Snowball sampling is the technique to determine the first sample, the following sample is going to be decided based on the information from the first sample, the third is chosen by the second informant, and so on that the amount of the sample grows like a snowball effect. In other words, the researcher interviews the key informant to gain some information, then finds the second, third informant, and so on till it is considered adequate.

\section{Research Location}

The research is located in CPA Firms in Malang City, Indonesia. The importance of quality control in audit as one of the instrument to maintain the quality of the product of CPA Firms is the background of why the researcher intends to study this phenomenon further. From the total amount of CPA Firms in Malang City, the 
researcher chose 3 CPA Firms to be the subject of the research. Initially, the researcher interviewed the key informant. After some information was collected from the key informant, second informant was done up to the data is adequate.

\section{Type and Source of Data}

In collecting the research data, this research uses primer data collected from the field research, those are from the interview with the board of CPA Firms and the auditor staff in Malang City. For secondary data, the researcher only managed to get the profile of CPA Firms because of the limitation in accessing secondary data from CPA Firms.

\section{Data Collecting Procedure}

Data was collected using the instrument of interview with the board of CPA Firms in Malang City. The interview process conducted was semi-structured interview which the researcher composed the main point of the questions related to the focus of the study and it still can be developed the interview is going.

\section{Research Findings And Discussion}

The quality control system implemented in the three CPA Firms in Malang City, the research subject, indicates some similarities in the form of the quality control system. This is shown from the results of the interviews with the informants. The discussion of the quality control system implemented in CPA Firms in Malang City according the aspects of the controlling system set in the standard of auditing will be explained in the sub-chapters follows.

\section{The Responsibility of CPA Firms Board towards the Quality}

As an organization, which provides professional accountant service, CPA Firms is led by partner and is formally regulated by standards set by the center of profession organization above them. According to the standards to be fulfilled, the board of CPA Firms build their own firm along with their own visions that is suitable with the statutory professionalism standards. Based on the utterance collecting by the researcher from all of the informants, quality and professionalism is the main purpose of CPA Firms in Malang City in providing public accounting service. In this case, it can be concluded that the board of CPA Firms are committed to maintain the quality of their service.

Board of CPA Firms, as the stakeholder who significantly contribute to the continuity of the organization, shall create a conducive working environment by setting up formal limitations that could build up harmony in order to make auditors feel comfortable in their workplace, as what the informant stated, "So I intend to build a particular character, that is familial.". The head/board should place themselves both as leaders and also colleague for all the staffs in order to make positive change to the staff's attitude to behave accordingly to the goal of CPA Firms, that is based on the standards and ethical code of professionalism as public accountant. As the research of Alberto et al. (2005) said that leadership positively and significantly affect people's performance and organization learning (in Trisnaningsih, 2007:5).

Furthermore, the board of CPA Firms do direct interaction informally with all the members of CPA Firms almost in everyday basis in order to understand the condition of every member. This can be seen from the result of the interview below.

"........because I go to the office every day, I almost never go to work, that is why I know what they are doing." From the interview, we can say that the more time the board of CPA Firms spent to interact with their member, the more chemistry occur between them. This shows that the board of CPA Firms always directly supervise all the members of CPA Firms.

The similarity in terms of standards and size of CPA Firms, small local firms, means that the quality control system implemented is more or less the same. The alikeness does not affect the contingency variable in CPA Firms in Malang City that is becoming the subject of research in terms of responsibility in leadership, thus based on the resemblance on this factor, the leadership responsibility of CPA Firms in Malang City does not support the theory of contingency.

\section{Independence}

Independence is a principle that shall be rooted in the mindset of a professional, especially editor in a CPA Firms. CPA Firms provides service that require the attitude and mental of a professional who prioritize integrity, ethic, and independence. In doing their job, the basic principles if professionalism ethics shall be obeyed without any objection, this will build the independence of the auditor. This is because the action of someone is affected by their attitude towards something, and their attitude is influenced by their mindset. Thus, the process of building someone's mindset is so essential in human resource management (Mulyadi dan 
Setyawan, 2001:67). In building and maintaining independency, CPA Firms in Malang City build a strong mindset in CPA Firms staffs in order to be independent.

CPA Firms struggle to assure their independence to each of their member start from their initiation in the workplace. From all the three research subjects, it is seen that during the recruitment process, competence and comprehension are two of the main factors in selecting the auditor. The assumption from the board of CPA Firms is that good competence and comprehension, means the recruits are having independent attitude that can be developed further when they have joined in the CPA Firms.

There are so many kinds of independency-related troubles that may appear during the job, such as financial-relationship with the client, giving both assurance and non-assurance service at the same time, and other special relationships that influence the auditors to set their professional ethics aside. In order to minimize the possibility that such disruption would affect the independency of an auditor, CPA Firms in Malang City tries to avoid those disruptions. Each CPA Firm always maintain the independency of all their personnel by executing their job according to the statutory standards. Besides, all CPA Firms, the subjects of this research, also add the statement of independency on the SPM that must be filled by each editor as a written formal oath of their independence attitude. That way, it can be assured that independency is a must and must be rooted and implemented well by CPA Firms in Malang City.

In conclusion, this finding shows that the result of the study on the model of quality control system of CPA Firms in Malang City, particularly in the aspect of independency, does not support the theoryof contingency. The reason behind this is the process of construction of independence attitude from each of the CPA Firms that is based on the same standard. Each of the leader and the personnel of CPA Firms has the same standard and reference through the main profession organization that are from the IAPI and IAI.

\section{The Acceptance and the Continuity of the Relationship with Clients}

Before initiating an engagement, CPA Firms will decide first whether the engagement will be accepted or not. The acceptance of the engagement must go through initial procedures that can give CPA Firms the information about the prospective client and the risks that might occur. A risk management process in the procedure of client acceptance is the important key in decreasing the business risk for the CPA Firms (auditor) in facing the litigation in the future (Johnstone, et. al, 2003).

CPA Firms must formulate a policy and controlling procedure to determine whether the engagement from the client will be accepted or even continued in minimizing the possibility of the relationship with the client whom management has no integrity (SPAP, SPM section 200). From the interview done, it shows that in the process of engagement acceptance, the three CPA Firms in Malang City become the subjects of research firstly need to dig and consider the information that related to prospective client such as the integrity, business nature of the client, as well as the suitability between the fee and the risk faced.

Besides, CPA Firms also consider the competence factor and the skill of the personnel of CPA Firms whether they are capable to do the engagement with the client. If it considered as not competence enough then CPA Firms will invite someone who is expert in the business of the client to help the engagement. The thing not to forget is the consideration upon the time needed in doing the engagement. If all the personnel of CPA Firms in one time has handled new audit jobs, then CPA Firms is not going to push themselves to remain accepting clients offering engagement.

"Why do you have to take more jobs if risky, rather we don't do it. Focus, prefect, and accountable," If seen from the quoted answer from the interview, principally CPA Firms in Malang City do not looking for as many client as they can without certain considerations. They think that it is better to have fewer client but the work is accountable and creating less risk for the CPA Firms.

After an engagement is initiated, in the process of closing, CPA Firms will do the presentation upon the client about the result of the engagement that has promised. The process also becomes the finalization / final phase from the engagement that has running for one period of deal. A CPA Firm is not only able to do the engagement with the clients only one time. This can create the possibility of continuation in relationship between CPA Firms and the client handled.

When a relationship with the client continued, CPA Firms will be easier in doing the adjustment upon the client and make sure whether the findings before has been followed up by the management of the client and whether the management letter on the previous engagement has been applied in the business of the client. This will surely help the running of the next engagement. However, apart from that continuity is not only become the indication of the professionality of the service provided by a CPA Firms, rather it is concerned that it will disrupt the independence if the closeness violate the standard limitations established.

On the CPA Firms of Malang City, each CPA Firm always keep a continued relationship with its client. The continued relationship with the client is considered as the way to ease the communication between the CPA Firms and the audited client. CPA Firms can get an easier way in delivering things that need to be concerned by the client on the next period in management letter, ease the CPA Firms in giving detail, and explain the results 
of the audit to the client for their better communication. In the other hand, if the client use that use the closeness and the continuity their relationship to disrupt the independence, CPA Firms will return to its ethical code and able to act strictly and refuse to continue such engagement.

The findings above can used to gain some conclusion that the form of the quality control done by the CPA Firms in Malang City in term of acceptance and continuity of the relationship with the client and certain engagement, is yet not supporting the theory of the contingency. There are similarities in the application of the system of quality control on the three CPA Firms observed.

\section{Human Resources}

The competence and carefulness are some of the principals of the professional ethics of an accountant. Accounting is a discipline that keeps evolving, where the practice on site always changing according to the condition of the economy and the condition of the company. CPA Firms as the provider of the service related to accounting, of course will consider the components of competence from each of the members. CPA Firms can evolve if the auditor that working inside has a good competence and skill, apart from also having integrity and independence. Human resources is the crucial factor in CPA Firms so that the leader of a CPA Firms is not only going to increase the credibility of the office, but also to keep developing the competence of the employee in order to expand and deepen the understanding upon accounting that is needed by CPA Firms.

With the development of each staffs, it will increase the competence of CPA Firms. The form of the upgrade here is not only gained from the development of the staff already working in the CPA Firms, but also through the recruitment of employees that is not done recklessly. If seen from the result of the interview of the researcher towards the leaders of CPA Firms, all create the similar answer in consideration about human resources. These uniformed answers then do not seemed to support the theory of contingency that used by the researcher because from the three CPA Firms that become the subjects of research have the similarity of answers and not creating only for creating the variable of contingency.

The first similarity is in each CPA Firms, the recruitment is done under certain requirement and by seeing how various aspects so that it can go in-line with the vision and mission of the CPA Firms entirely. Each of the CPA Firms in Malang City really concern the human resources that they employ. This thing described from the system and procedure of recruitment that present in each CPA Firms where entirely the CPA Firms establish the competence as the solid basic in determining new staffs, supported by the ability to cooperate with the partners as the team and also work ethics of the prospective employee. From the result of the three interview of the CPA Firms, the minimum requirement in the acceptance in the competence and the skill in accounting and tax. Besides, each of the CPA Firms aslo consider the other soft skill and the hard skill mastered by the prospective staff.

Secondly, not only by strengthening and by creating a more strict process of recruitment, for the existing human resources inside the CPA Firms, all the CPA Firms facilitate their staffs with the training either in the form of PPL held by the main organization of profession such as IAPI dan IAI that routinely scheduled. As well as the development of competence and the team cooperation internally through the regular studying of material and outbound. Apart from the ways of the leaders in developing the competence of the staffs, the entire CPA Firms has tried to make sure that the human resources that they own are the human resources that are competent and able to develop so that it can provide the audit service well.

\section{The Implementation of Engagement}

In providing their professional service, CPA Firms have the specific procedure that is made in doing their job. The procedures are the protocol that must be fulfilled by each of the personnel according to their parts. The initial procedure that also involve the leader of the CPA Firms is the procedure of the pre-engagement that is also the important factor in the running of the engagement. In this procedure, CPA Firms do some investigation upon the business of the clients and finding the understanding to create an engagement then CPA Firms will run the process of engagement.

From the result of the interview, it is gained by the researcher that in the CPA Firms in Malang City shows the similarities of quality control in maintaining the engagement here this then does not support the theory of contingency. There are several similarities, first on the initial procedure of the engagement that is making of a team and the discussion in the process of engagement, where each CPA Firms have the same consideration in making the audit team to do a engagement. The making of the team based on the previous purpose, skill and experience of the auditor on the sector business of the client, as well as the availability of time of every member of the team in doing the job. The difference of the shape and sector of business is one of the challenges and the important point of consideration in making the audit team. So that there are similar understanding of statement about the skill, experience, and competence is the important base in term of team structure that run an engagement. As well as the limitation of number of employee that of course affecting the construction of an audit team so that the engagement can be done optimally and still keeping the quality. 
In implementing the engagement, the supervising process is always done. From the result of the interview on the three informants, it is known the supervision is done periodically that begins from the team leader, then supervisors/managers, and the last one is the partner as the leader of CPA Firms. Supervision is not only done in the end of the implementation of the engagement, but since the beginning of the engagement, that is the data collecting process until the finalization of the result of the audit findings. The total clients that still can be reached cause the CPA Firms leader to be actively joining as well as supervising the implementation of the engagement from the beginning until the end. The leaders are not sit back and merely doing the review only when the implementation of the engagement is finished. Like what is seen in the result of the interview upon the informant “...I jump right in. so I don't only sit in my desk all the time, I don't revise either. At certain point according to the evaluation of the client's condition, then I follow."

The findings imply that the supervision process that is done by participating directly and giving support to the staffs in implementing the engagement in increasing the wok of the staffs. This is in-line with the findings found by Miller and Monge (1986) in Slamet (2002:14) stated that the ability of supervision in giving technical help and support to the behavior of the employee could grow the work satisfactory of them. Then also with the participative atmosphere created by the supervisor can have a substantial effect upon the work satisfactory rather than doing the participation in one particular decision only.

The conclusion that can be drawn from the discussion of the research findings above is that in implementing the engagement, quality control done by the CPA Firms in Malang City are: 1) CPA Firms concern the ability and the workload of the staffs that implementing the engagement, 2) while the engagement is implemented, there will always a supervision done periodically and the leaders participate directly in the working of an audit engagement. From the result, it is seen that it does not support the theory of contingency because there is no contingency variable affect the application of the quality control system. Again, this is caused by the contextual factor that are the same in all the three CPA Firms.

\section{Monitoring}

The qualified audit result become the main goal on each engagement that done by the CPA Firms. To achieve the quality control to make sure that the work of the CPA Firms member are well in every work. The main thing that become the monitoring object are the human resources on the CPA Firms and the work result that can be seen on the worksheets.

Based on the result of interview with the leaders of the CPA Firms, the things done to evaluate every human resources working in the CPA Firms is by filling the evaluation sheets. In addition, the personal approach by the leaders themselves to make sure that the human resources working in the CPA Firms always maintaining their professionalism, integrity, and independence as the public accountant. Besides, whenever an engagement is done, the entire personnel of the CPA Firms will have a meeting to evaluate and review the worksheets. This is done in order to look for the lack on the process of the implementation so that it can be anticipated for the following the engagement.

While externally, all the CPA Firms will get the monitoring and supervision from the IAPI as the main organization of the profession and regular reviewing to each other of all the fellow accountant offices. The evaluation done is meant to see whether the system of quality control is done entirely by the CPA Firms offices in Malang City.

From the findings of the research, a conclusion can be drawn that the CPA Firms in Malang City always do the monitoring both internally in the scope of on CPA Firms office and externally. The supervising done is related to the quality of the CPA Firms that is the monitoring upon the human resources working in the CPA Firms, the monitoring of working result through the review of the worksheet, and the supervision of the entire quality control system.

\section{Conclusion}

The result of the research indicate that the CPA Firms in Malang City, that is subject of the research that is classified as the small local firm, has run the quality control system of CPA Firms that refer to the auditing standard that has been established. In doing the quality control, CPA Firms fulfill the six principals of quality control, those are; the responsibility of leadership, the requirement professional ethics that applied, acceptance and continuation of the relationship with the clients and certain engagement, human resources, implementation of engagement, and supervision.

By using the six principals, the CPA Firms has done the quality control that create a good auditor work output so that it resulted a good quality audit. The model of the quality control on each CPA Firms have some similarities where the informal control more likely to be done and the leader is the part who take the most responsibility upon the running of the control. The similarity in form of control here is due to the same contextual factors of CPA Firms and the obedience of each CPA Firms in the standard and the same ethic code of profession. 


\section{Limitation Of Research}

There are some thing that become the limitation that need to be considered when evaluating this research.

1. CPA Firms that becomes the subject of the research have the relatively same general description which cause the failure in supporting the theory of contingency in describing the form of system in quality control of audit in those CPA Firms that become the theoretical basis in this research.

2. The small scope of the research done that can cause this research to be hardly generalizable. It can be that in different place and condition, the findings will show different results.

\section{Suggestion}

Based on the limitation above, the researcher proposes several suggestion as follow.

1. The future research is expected to use the research subject that have different general description (i.e. a large scale, medium scale, and small scale of CPA Firms) to see whether there will a varied form of quality control upon the audit.

2. The research done here is only a small portrait that the researcher tried to deliver, it is better if the future researchers expand the scope into a larger picture.

[1]. Creswell, John. W. 2007. Qualitative Inquiry and Research Design: Choosing Among Five Approaches( $2^{\text {nd }}$ ed). Thousand Oaks, CA: Sage.

[2]. 2014. Research Design Pendekatan Kualitatif, Kuantitatif, dan Mixed. Yogyakarta: Pustaka Belajar.

[3]. DeAngelo, Linda E. 1981. "Auditor Size and Audit Quality”. Journal of Accounting and Economics 3, pp: 183-199.

[4]. Fisher, G. Joseph. 1998. Contingency Theory, Management Control System and Firm Outcome: Past Results and Future Directions. Behavioural Research in Accounting, Vol. 10.

[5]. Institut Akuntan Publik Indonesia (IAPI). 2011. Standar Profesional Akuntan Publik. Jakarta: Salemba Empat.

[6]. Johnstone, Karla, M; Bedard, Jean, M. 2003. "Risk Management in Client Acceptance Decision". The Accounting Review, Vol. 78, 4, ABI/INFORM Global, pg. 1003.

[7]. Ludigdo, Unti dan Machfoedz, Mas'ud. 1999. "Persepsi Akuntan dan Mahasiswa Tentang Etika Bisnis". Jurnal Riset Akuntansi Indonesia, Volume 2(1), Halaman 1-19.

[8]. Mulyadi dan Setyawan, Johny. 2001. Sistem Perencanaan dan Pengendalian Manajemen. Edisi ke-2, Cetakan ke-1. Jakarta: Salemba Empat.

[9]. Nugroho, Adi dan Chariri, Anis. 2012. "Studi Fenomenologi tentang Peran Akuntan dalam Masyarakat: Melayani Kepentingan Publik atau Kepentingan Klien?”. Diponegoro Journal of Accounting, Volume 1, Nomer 1, Tahun 2012, Halaman 1-8.

[10]. Slamet, Budiman. 2002. "Pengaruh Tindakan Supervisi terhadap Kepuasan Kerja Auditor yang Melakukan Audit Khusus: Studi Empiris pada Kantor Perwakilan BPKP”. Tesis Universitas Diponegoro.

[11]. Trisnaningsih, Sri. 2007. "Independensi Auditor dan Komitmen Organisasi sebagai Mediasi Pengaruh Pemahaman Good Governance, Gaya Kepemimpinan dan Budaya Organisasi terhadap Kinerja Auditor”. Prosiding Simposium Nasional Akuntansi X, 26-28 Juli, hlm. 1-56. 